b al

b. 9 ' DOE/FE-022OP-2

\title{
Strategic Petroleum Reserve Quarterly Report
}

SEP 031991

August 15, 1991

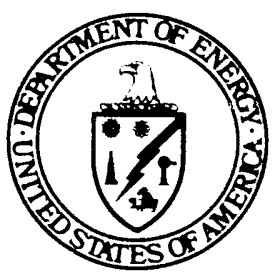

Department of Energy

Assistant Secretary for Fossil Energy Office of Strategic Petroleum Reserve 
$\mathrm{DOE} / \mathrm{FE}--0220 \mathrm{P}-2$

DE9 2003034

\section{Strategic Petroleum Reserve Quarterly Report}

August 15, 1991

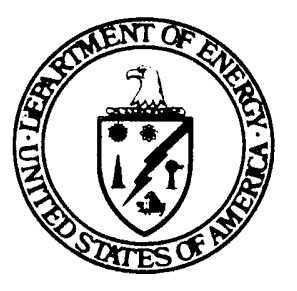

Department of Energy

Assistant Secretary for Fossil Energy Office of Strategic Petroleum Reserve Washington, DC 20585 


\section{TABLE OF CONTENTS}

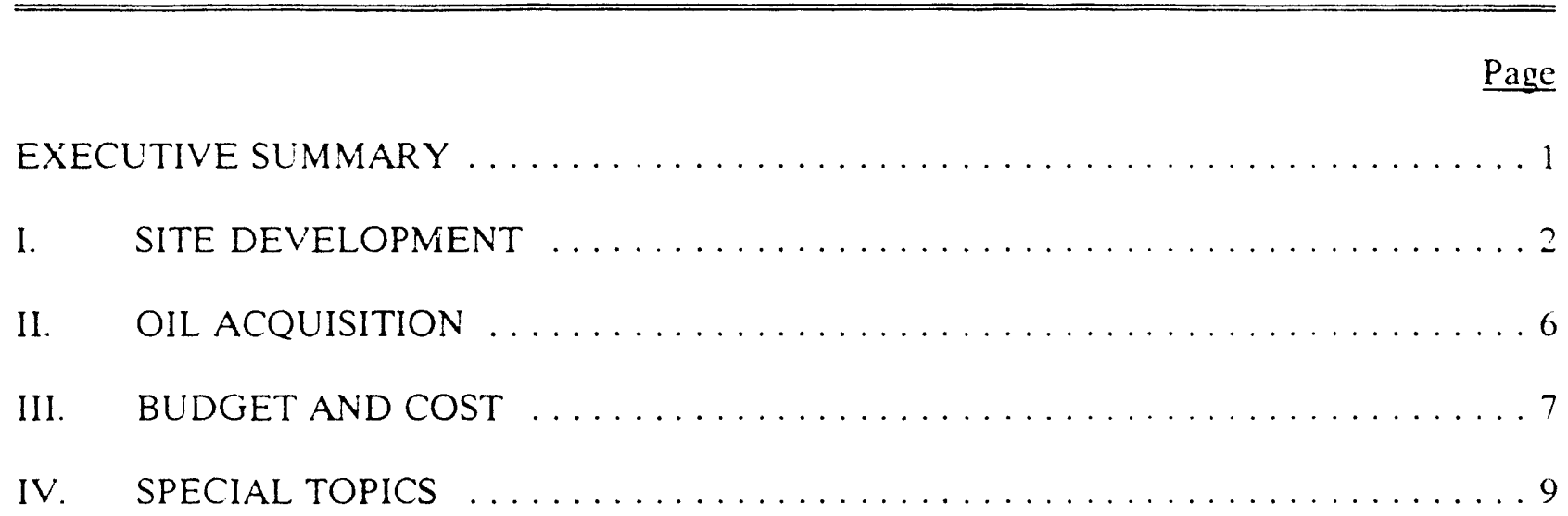

\section{TABLES}

I-1 STRATEGIC PETROLEUM RESERVE CAPACITY DEVELOPMENT $\ldots \ldots \ldots 5$

I-2 CURRENT AND PROJECTED AVAILABLE STORAGE CAPACITY $\ldots \ldots \ldots . .5$ 


\section{EXECUTIVE SUMMARY}

The Strategic Petroleum Reserve was created pursuant to the Energy Policy and Conservation Act (Public Law 94-163), approved on December 22, 1975, and extended in July 1985 , June 1989, March 1990 and September 1990, to reduce the impact of disruptions in petroleum supplies and to carry out obligations of the United States under the Agreement on an International Energy Program. The Strategic Petroleum Reserve Quarterly Report is submitted in accordance with section 165(b) of the Energy Policy and Conservation Act, as amended, which requires that the Secretary of Energy submit quarterly reports to Congress on activities undertaken with respect to the Strategic Petroleum Reserve. This August 15, 1991, Strategic Petroleum Reserve Quarterly Report describes activities related to the site development, oil acquisition, budget and cost of the Reserve during the period April 1, 1991, through June 30, 1991.

The Strategic Petroleum Reserve storage facilities development program is proceeding on schedule. The Reserve's capacity is currently 726 million barrels. A total of 5.5 million barrels of new gross cavern volume was developed at Big Hill and Bayou Choctaw during the quarter.

There were no crude oil deliveries to the Strategic Petroleum Reserve during the calendar quarter ending June 30, 1991. Acquisition of crude oil for the Reserve has been suspended since August 2,1990, following the invasion of Kuwait by Iraq. As of June 30, 1991, the Strate- gic Pctroleum Reserve inventory was 568.5 million barrels.

The reorganization of the Office of the Strategic Petrolcum Reserve became effective June 2S, 1991. Under the new organization, the Strategic Petrolcum Reserve Project Management Office in Louisiana will report to the Strategic Petroleum Reserve Program Office in Washington rather than the Oak Ridge Field Olfice in Tennessec. 


\section{SITE DEVELOPMENT}

The Department of Energy has been involved since 1976 in a major storage lacilities development program to stockpile crude oil. Over the last 15 years, the Department has acquired and developed six underground crude oil storage facilities in salt domes along the Gulf coasts of Texas and Louisiana, and a marine terminal on the Mississippi River at St. James, Louisiana. The six storage sites are Bayou Choctaw, Weeks Island, West Hackberry and Sulphur Mines in Louisiana, and Bryan Mound and Big Hill in Texas. These storage sites are organized into three distribution systems and connected by Department of Energy pipelines to commercial crude oil pipeline networks and commercial and U.S. Government-owned marine distribution terminal facilities. The Strategic Petroleum Reserve facilities development program is presently directed toward providing a total storage capacity of 750 million harrels and a drawdown/distribution capacity of 4.5 million barrels per day.

\section{FACILITIES DEVELOPMENT STATUS}

\section{Bryan Mound}

The Bryan Mound site is located in Brazoria County, Texas, approximately three miles southwest of Freeport. The Department acquired this storage site in 1977 and converted tour existing brine caverns with a total capacity of 66 million barrels to oil storage. Subsequently, the Department expanded this site to 226 million barrels through the solution mining of 16 additional 10 million-barrel caverns. The expansion was comricted in 1986 and oil fill is near completion.

In 1992, the Department plans to replace the entire 2.1-mile onshore section of the brine disposal pipeline and shorten the offshore section from 12.5 miles to 4.6 miles. The relocation of the diffuser to the 4.6 mile offshore position has been approved by the EPA. Replacement of the pipeline will require National Environmental Policy Act (NEPA) review and at least an Environmental Assessment. The Department commenced environmental assessment and enginecring design activities in May 1991. Fabrication of the new pipeline is planned to commence in mid-1992. Construction will be completed May 30, 1993.

On June 28, 1991, all non-essential operalions were suspended at Bryan Mound pending the results of an investigation of the root cause of a series of recent operational mishaps and noted maintenance deficiencies. Completion of the investigation is scheduled for September with resumption of full operational capability to occur as soon thereafter as necessary corrective measures can be implemented.

\section{West Hackberry}

The West Hackberry site is located in Cameron Parish, Louisiana, approximately 22 miles southwest of Lake Charles. The Department acquired this storage site in 1977 and converted five existing brine caverns with a capacity of 49 million barrels to oil storage. Subsequently, the Department expanded this 
storages sile through solution mimmer of 1 - addilional lo million-harrel writge ciserns. Development of this site w the planned kevel ot 219 million harrels was cimpleked in seplember Iysis.

\section{Sulphur Mines}

The Sulphur Mines site is located in Calcisicu Parish. Louisiana, approximately 12 miles west of Latke Charles. The Department acyuired this storige site in 1999 and converted three evisting brinc calcerns with a capacity of 26 million barrels (1) crude oil storage. Development and till of this site were completed in 1983.

The Department's development plan for the SPR provides lor consolidating the Sulphur Mincs inventory into existing larger sites to increase the Resences cost effectiveness. Specifically, the Department is expanding the Big Hill facility hy 21) million harrels and the Bayou Choctaw licility by o million barrels to replace the Sulphur Miness storage capacity.

The Department issued a competitive Invitation lior Bids (IFB) tor the sale of the tacility on Junc 17, 1991. The IFB will close on September 17. 1991. Plans have been initiated to transter the site to a new owner during the second quarter of 1992 or to the General Services Administration by the tourth quarter should the site not be purchased by an industrial tïrm.

As of the end of this quarter, nearly 11 million barrels of oil have been moved to the Big Hill sitc. Completion of oil transfer is anticipated in late 1991.

\section{Big Hill}

The Big Hill storage site is located in Jeflerson County. Texas. 20 miles southwest of Bealumont. The Department acquired this undeveloped site in 1982 and has been constructing a new storage facility with a planned storage ciapacity of 160 million barrels and a drawdown capability of 9.30 .000 barrels per day. The site's planned total capacity includes 20 million barrels of storage capacity to replace a portion of that lost through the planned decommissioning of the Sulphur Mines site.

Construction of all major surlace facilities at Big Hill has been completed. Cavern development continues on schedule. Twelve of the 14 caverns have been completed and the remaining two caverns are 96 percent complete. The total planned capacity of 160 million barrels is projected to be completed in September 1991.

\section{Bayou Choctaw}

The Bayou Choctaw site is located in Iberville Parish, Louisiana, approximately 12 miles southwest of Baton Rouge. The Department acquired this storage site in 1977 and converted four existing brine caverns with a capacity of 46 million barrels to oil storage. Subsequently, the Department acquired a fifth existing cavern (No. 17) through an exchange agreement with Union Texas Petroleum.

During this quarter, Cavern 18 was enlarged by 1.2 million barrels bringing the cavern to approximately 95 percent completion. Cavern leaching remains on schedule and is anticipated 
to he completed in September 1991, at which time the site's planned total storige capacity of i2 million harrcls will he achieved.

\section{Weeks Island}

The Weeks Island site is located in Iberia Parish. Louisiana. approximately 95 miles southwest of New Orleans. The Department acquired this storage site in 1977 and converted an existing conventional salt mine with a capacity of 73 million barrels to oil storage. Development and till of this site were completed in 1982. The site is currently in an operational stanclby mode.

As part of the Weeks Island mine integrity assurance program, the Department plans to isolate Morton International Inc.'s Markel Mine Irom the Strategic Petroleum Reserve operations area by constructing new bulkheads. Responses to an Invitation for Bids (IFB) tor construction are due in July 1991 with contract award anticipated in August. Completion of construction is anticipated in mid-199?.

The Department has plans to install a backup or alternate drawdown capability to the existing 11-pump system located in the service shatt by acquiring submersible recovery pumps which could be placed into the mine oil-fill holes. Responses to an earlier Department solicitation were deemed to be unacceptable in terms of technical feasibility and costs and therefore the single-site criteria for recovery pumping capacity was waived at Weeks Island to allow for use of a lower tlow rate but technically feasible back-up pumping system. The recovery criteria for the total Reserve system, however, remains in effect.
A new solicitation tor downhole recovery pumps capable of supporting a 160.000 barrel-per-daly drawdown is expected to be issued in early August.

\section{DISTRIBUTION ENHANCEMENT SIATUS}

The SPR has a current distribution capahility of 3.5 million barrels per day. Distribution enhancement projects are planned or in progress to increase this capability to 4.5 million barrels per day for the 750 million-barrel Reserve.

Site piping and pumping system modilications at Bryan Mound, designed to increase the site's drawdown/distribution rate from 1.1 million barrels to 1.25 million barrels per day, are approximately 92 percent complete as of June 30 . 1991. Completion of construction is scheduled for late August. Start-up testing is planned tor September 1991.

The Department's solicitation for 700,000 barrels per day of commercial marine and/or pipeline distribution services within the Texoma Group closed on May 15, 1991. Several proposals were received and are currently being evaluated. Contract awards are planned for September 1991.

\section{CURRENT AND PROJECTEI) STORAGE CAPACITY}

As of June 30, 1991, the SPR's total available storage capacity was 726 million barrels. A total of 5.5 million barrels of new gross cavern volume was developed at Big Hill and Bayou Choctaw this quarter, as shown in Table I-1. 
The SPR will complete its 750 million barrel dwilopment next quarter with the completion of the last mo caverns at Big Hill and the Cavern is inlargement at Bayou Choctaw. Projected storage capacity and cummulative oil till capability by liscal year are shown in Table 1-2. Oil till capability is based on the maximum fill rates for the storage sites.

\section{TABLE I-1 \\ Strategic Petroleum Reserve Capacity Development (million barre!s)}

\begin{tabular}{|c|c|c|c|}
\hline \multirow[b]{2}{*}{ Storage Facility } & & \multirow[b]{2}{*}{$\begin{array}{c}\text { Cumulative } \\
\text { Storage Capacity } \\
\text { June } 30,1991\end{array}$} \\
\hline & $\begin{array}{l}1991 \text { Apr-Jun } \\
\text { Gross Volume } \\
\text { Created } \\
\end{array}$ & $\begin{array}{c}1991 \text { Apr-.Jun } \\
\text { Storage Volume } \\
\text { Created }\end{array}$ & \\
\hline Big Hill & 4.3 & 23.0 & 138.0 \\
\hline Bryan Mound & - & - & $226.0^{1 /}$ \\
\hline West Hackberry & - & - & $219.0^{1 !}$ \\
\hline Bayou Choctaw & 1.2 & 0.0 & 56.0 \\
\hline Weeks Island & - & - & $73.0^{2 /}$ \\
\hline Sulphur Mines & - & - & $14.0^{3 /}$ \\
\hline TOTAL & 5.5 & 2.3 .0 & 726.0 \\
\hline
\end{tabular}

Storage development completed.

$\doteqdot \quad$ Storage development and oil fill completed.

$\therefore \quad$ Storage capacity based on the current oil inventory. Site oll transter in progress in preparation tor decommissioning in FY 1992.

TABLE I-2

Current and Projected Available Storage Capacity (million barrels)

\begin{tabular}{rcc} 
& Storage Capacity & $\begin{array}{c}\text { Cumulative Oil } \\
\text { Fill Capability }\end{array}$ \\
\cline { 2 - 3 } Current (June 30, & 726 & 568 \\
$1991)$ & & 622 \\
End of FY 1991 & 750 & 750
\end{tabular}




\section{OIL ACQUISITION}

There were no crude oil deliveries to the Strategic Petroleum Reserve during the calendar quarter ending June 30, 1991. Since August 2. 1990. when Iraq invaded Kuwait, the acquisition of crude oil to fill the Reserve has been suspended. Current plans are to resume crude oil acquisition and fill activities during fiscal year 1992.

As of the end of the quarter, the Strategic Petroleum Reserve inventory was 568.487.663 barrels. 


\section{BUDGET AND COST}

This section provides the financial intormation required by section 165(b) of the Energy Policy and Conservation Act, as amended.

\section{FUNDS AVAILABLE FOR OBLIGATION}

Estimated funds available for obligation in fiscal year 1991 consist of $\$ 650$ million in the SPR Petroleum Account and $\$ 260$ million in the Strategic Petroleum Reserve Account. These funds include $\$ 315$ million collected as a result of the Operation Desert Storm drawdown. At the present time, no Naval Petroleum Reserve receipts in excess of $\$ 638$ million. as provided by the Department of Interior and Related Agencies Appropriations Act for fiscal year 1991 (Public Law 101-512), are projected for deposit in the SPR Petroleum Account during lïscal year 1991.

\section{OIL ACQUISITION AND TRANSPORTATION (SPR PETROLEUM ACCOUNT)}

This activity incluctes financing for: (1) the Strategic Petrolcum Reserve crude oil procurements; (2) associated transportation costs for pipeline and tanker shipments and terminalling: (3) U.S. customs duties and Superlund taxes: and (4) other miscellaneous costs, such as Defense Fuel Supply Center administratiun costs associated with acquiring and transporting the oil. During a drawdown and sale, this activity funds the Federal cost of drawing down Strategic Petroleum Reserve oil from storage and trans- porting it to the point where purchasers would take title.

FINANCIAL TRANSACTIONS, THIRD QUARTER OF FISCAL YEAR 1991

During the third quarter of fiscal year 1991 . $\$ 3$ million was obligated from the SPR Petroleum Account. Fiscal year 1991 obligations through the third quarter were $\$ 9$ million. Net dishursements (outlays) from the Account during the same period amounted to approximately $\$ 16$ million.

\section{PLANNED USE OF SPR PETROLEUM AC- COUNT FUNDS}

Of the estimated $\$ 650$ million of SPR Petroleum Account funds available for obligation. approximately $\$ 641$ million were not obligated at the end of the third quarter.

These funds will support oil acquisition and transportation activities into fiscal year 1992.

\section{STORAGE FACILITIES DEVELOPMENT AND OPERATIONS AND MANAGEMENT (STRA- TEGIC PETROLEUM RESERVE ACCOUNT)}

Storage Facilities Development and Operations tunding provides for the Strategic Petroleum Reserve facilities program, including the construction, operation, and maintenance of the Strategic Petroleum Reserve sites. Management funding provides for analyses pertinent to major issues concerning the development and use of the Strategic Petroleum Reserve and for the 
salaries and expenses necessary to plan and manage the Strategic Petroleum Reserve.

FINANCIAL TRANSACTIONS, THIRD QUARTER OF FISCAL YEAR 1991

Of the $\$ 260$ million available during tiscal year 1991 for obligation for Storage Facilities Development and Operations and Management, $\$ 11$ million were obligated in the third quarter. Cumulative net obligations for fiscal year 1991 were approximately $\$ 122$ million at the end of the third quarter.

\section{PLANNED USE OF FACHLITIES AND MAN-} AGEMENT FUNDS

The remaining $\$ 138$ million available for Storage Facilities Development and Operations and Management is currently planned for obligation by the end of fiscal year 1991 . 


\section{SPECIAL TOPICS}

\section{CANDIDATE SITES FOR A BILLION BAR- REL STRATEGIC PE'TROLEUM RESERVE}

In May, the Department published a "Notice of Intent" in the Federal Register to announce its plan to prepare an Environmental Impact Statement (EIS) evaluating the alternatives for expanding the Reserve to one billion barrels and to announce public scoping meetings and solicit comments.

A brochure was prepared and widely distributed to publicize the meetings and help the public and cognizant Federal, state, and local agencies to understand what is being proposed. In addition, legal advertisements were placed in major regional newspapers. Altogether, 24 local newspapers, fourteen television stations and four radio stations were contacted.

The scoping meetings were held June 4, 1991, in Lake Jackson, Texas, and June 6, 1991, in Thibodaux. Louisiana. Attendance was light.

Seventeen people spoke in addition to the brief presentations by the Department. No new alternatives were proposed and no new unexpected environmental issues surfaced. Most of the public comments were socioeconomic in nature.

The results of the scoping process will be summarized in the EIS Implementation Plan which will establish the scope, structure and outline of the EIS. The Implementation Plan is expected to be available in August 1991.

\section{STRATEGIC PETROLEUM RESLRVE RE- COVERY PROGRAM}

The Strategic Petroleum Reserve's Recovery Program provides for rapid repair of drawdowncritical systems if necessary during an energy emergency. Delays have been experienced in the implementation of the Recovery Program over the past nine months due to the SPR Desert Storm drawdown and technical obstacles that have caused procurement delays and cancellations. The major procurements for site-specific manifolds, valves, piping pumps and motors tor the recovery program are under contract for delivery by February 1992 lor all SPR sites except the Weeks Islands site. A delay has been experienced in procurement of submersible pumps for the Weeks Island site which has been canceled twice due to non-rcsponsive bids. Full achievement of a recovery capability for all sites is now scheduled for August 1992.

\section{SECURITY}

On March 20, 1991, the Department of Justice signed Arrest Authority Implementa.ion Guidelines authorizing the Reserve to make arrests and entorce Federal oltenses such as trespassing and malevolent acts on tederallyowned Strategic Petroleum Reserve facilities. Planned implementation of this arrest authority has been delayed due to a procedural change requiring publication of the Arrest Authority Guidelines in the Federal Register as a "Notice of Proposed Rulemaking." Following this publi- 
cation. there will be a 30-day comment period and a 3() -day wating period. Publication in the Federal Register is expected in July 1991. All Strategic Petroleum Reserve-related actions. however. including training. and the printing and preparation of credentia's will be completed in time to support implementation.

\section{NEW MANAGEMENT STRUCTURE}

As part of the Secretary of Energy's initiatives to establish clearer lines of management authority and accountability throughout the Depar. knt, the Strategic Petroleum Reserve (SPR.) Program Management structure changed in June. The SPR Project Management Otfice now reports directly to the SPR Program Otilice at DOE headquarters rather than through the Oak Ridge Field Oftice The SPR Program Ottice was also reorganized to accommodate its more direct oversight and managemient role. The reorganization included the addition of stall resources. 

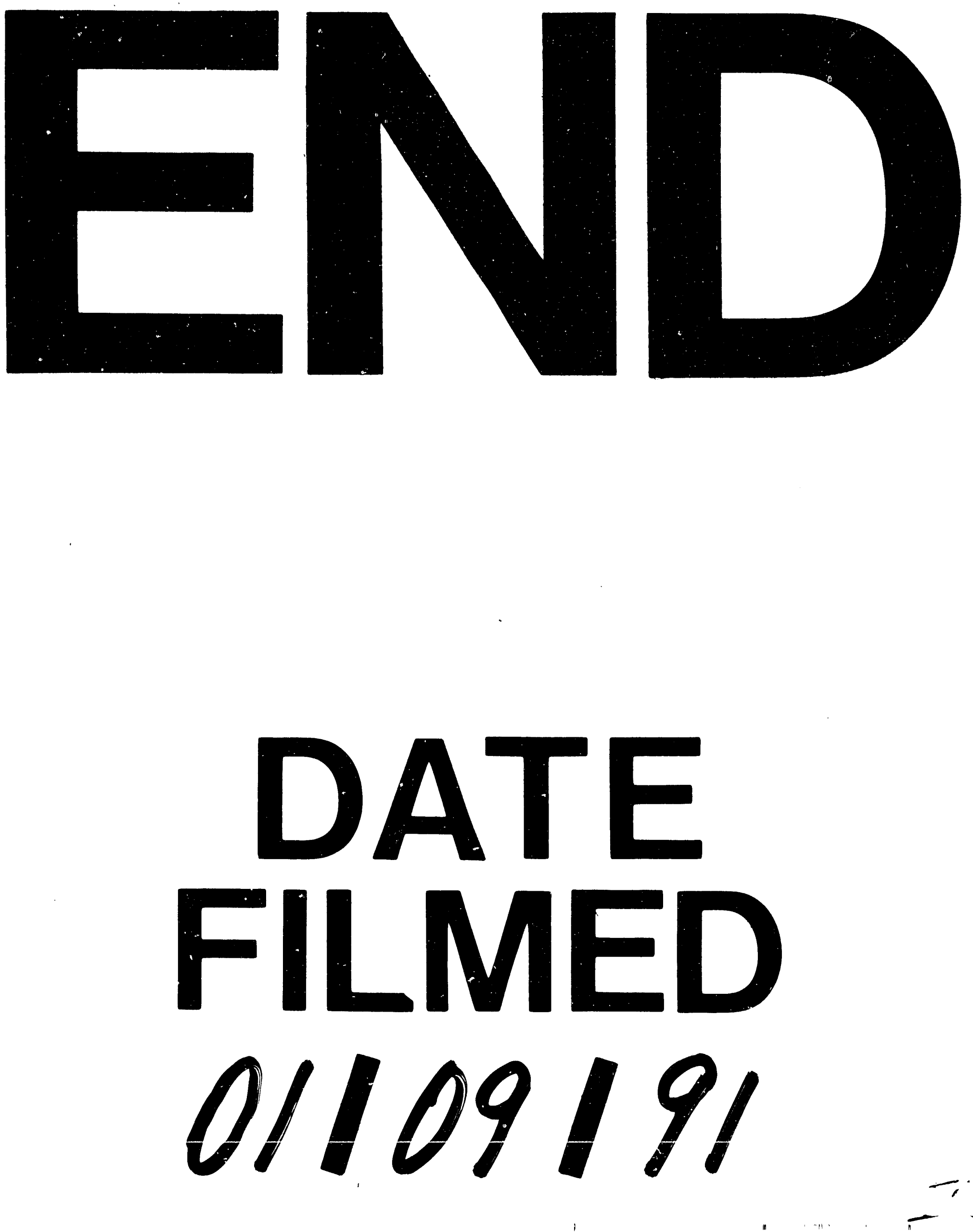

- 
